\title{
KOMUNIKASI STRATEGIK DALAM PENYELESAIAN KONFLIK AGRARIA DI INDONESIA
}

\author{
Yuhdi Fahrimal $^{1}$, Safpuriyadi ${ }^{2}$ \\ ${ }^{1}$ Dosen Prodi Ilmu Komunikasi, Universitas Teuku Umar \\ ${ }^{2}$ YLBHI-Lembaga Bantuan Hukum Banda Aceh \\ Email: fahrimalhazmi@gmail.com
}

\begin{abstract}
Abstrak
Konflik agraria antara komunitas adat dengan perusahaan perkebunan sawit di Indonesia masih terus terjadi. Ekspansi lahan perkebunan kelapa sawit, pertarungan klaim atas tanah, serta tumpang tindihnya kebijakan ijin usaha perkebunan kepala sawit menjadi penyebab semakin banyaknya konflik agraria. Penelitian ini bertujuan menganalisis strategi komunikasi dalam penyelesaian konflik agraria di Desa Cot Mee, Kabupaten Nagan Raya. Konflik agraria antara masyarakat Desa Cot Mee dengan PT. Fajar Baizury \& Brothers telah berlangsung sejak lama. Konflik ini didasari tindakan penggunaan lahan oleh perusahaan perkebunan sawit seluas 314 ha yang diklaim masyarakat sebagai tanah adat. Upaya penyelesaian yang dilakukan masih bersifat parsial dan belum menemukan titik temu. Kegagalan pemerintah daerah sebagai mediator disebabkan oleh posisi dilematis pemerintah daerah karena terkait dengan penerimaan pajak daerah dari perusahaan perkebunan sawit. Dalam upaya penyelesaian konflik agraria di Desa Cot Mee, perspektif Communication Strategic (Silvio Wasibord, 2014) dapat digunakan melalui lima tahapan penyusunan strategi, yaitu, (1) problem definition; (2) goal selection; (3) strategy junctures; (4) tactics; dan (5) people's motivations for change.
\end{abstract}

Kata Kunci: Strategic Communication, Konflik Agraria, Tanah Adat

\begin{abstract}
Agrarian conflict between indigenous communities and oil palm plantation companies in Indonesia continues to occur. The expansion of oil palm plantations, claims to land claims, and the overlapping of palm oil plantation permit policy are the cause of the increasing number of agrarian conflicts. This study aims to analyze the communication strategy in the settlement of agrarian conflict in Cot Mee Village, Nagan Raya District. Agrarian conflict between the people of Cot Mee Village and PT. Fajar Baizury \& Brothers has been going on for a long time. This conflict is based on land use actions by palm oil plantation corporation claimed by the community as customary land. The settlement efforts are still partial and have not found a common ground. The failure of local government as a mediator is caused by the dilemma position of local government because it is related to local tax revenue from palm oli plantation corporation. In the effort to solve agrarian conflict in Cot Mee Village, Communication Strategic perspective (Silvio Wasibord, 2014) can be used through five stages of strategy formulation; (1) problem definition; (2) goal selection; (3) strategy junctures; (4) tactics; and (5) people's motivations for change.
\end{abstract}

Keywords: Strategic Communication, Agrarian Conflict, Indigenous Land 


\section{PENDAHULUAN}

Eksistensi perkebunan sawit di Indonesia berada dalam dua sisi mata pisau. Di satu sisi keberadaan perkebunan sawit menguntungkan bagi pendapatan daerah dan negara yang peruntukannya untuk kesejahteraan masyarakat. Namun, di sisi lain perkebunan sawit menyisakan sekelumit permasalahan agraria khususnya dengan masyarakat setempat (Cifor, 2016. Hal ini didasari oleh semakin tingginya ekspansi perkebunan kelapa sawit di Indonesia. Berdasarkan Data Statistik Perkebunan Indonesia Komoditas Kelapa Sawit 20142016 yang diterbitkan oleh Direktorat Jenderal Perkebunan, Kementerian Pertanian menunjukkan bahwa luas lahan Perkebunan Kelapa Sawit di Indonesia sampai tahun 2016 adalah 11.672.861 hektar. Dari besaran luas lahan ini, perkebunan yang dikuasai oleh perusahaan swasta memiliki luas lahan paling dominan, yaitu, 6.153.277 hektar (Dirjen Perkebunan, 2015).

Ekspansi besar-besaran perkebunan kelapa sawit dianggap sebagai ancaman bagi ekologi (Fitzherbert et al. 2008). Luasnya lahan kelapa sawit di Indonesia menyebabkan beberapa permasalahan, seperti, degradasi luas hutan tropis, praktik illegal logging, alih fungsi lahan pertanian rakyat (Richardson, 2010; Wicke et al, 2011), kebarakan hutan, polusi, erosi, pelanggaran Hak Asasi Manusia, paparan pestisida, perselisihan buruh, perlakukan tidak adil pada petani kecil, dan eksploitasi tenaga kerja perkebunan (Wakker dan Rozario, 2004). Pembukaan lahan perkebunan kepala sawit telah ikut hancurnya keanekaragaman hayati -khususnya Orang Utan (Nantha dan Trisdell, 2009) dan mengancam ketahanan pangan masyarakat (Rahman et al, 2008).

Angka konflik masyarakat dengan perusahaan kelapa sawit terus meningkat. Pada tahun 2011 menurut Badan Pertanahan Nasional, telah terdaftar sekitar 3.500 konflik lahan yang didominasi sengketa masyarakat dengan perusahaan kelapa sawit (Colchester dan Chao, 2011). Konflik antara masyarakat dengan perkebunan kelapa sawit ini disebabkan kurangnya transparansi perusahaan terhadap luas lahan, tidak sesuainya pembagian keuntungan, serta ketidakjelasan hak atas tanah (Rist dan Levang, 2010). Perusahaan yang bekerja sama dengan pemerintah cenderung memanfaatkan lahan masyarakat -tanah ulayat melalui pembelian dengan harga murah untuk digunakan dalam perluasan lahan perkebunan (Mutolib et al, 2016).

Konflik agraria -khususnya perkebunan sawit - merupakan konflik pertentangan apa yang disebut oleh Hall et al (2011) sebagai land exclusion. Dalam konsep ini, mereka melihat bagaimana lahan atau tanah dilihat dalam kerangka akses. Akses diartikan sebagai kemampuan untuk memperoleh manfaat dari sesuatu (the ability to derive benef it from things). Definisi ini lebih luas dari pengertian klasik tentang properti, yang didefinisikan sebagai hak untuk memperoleh dari sesuatu (the right to benef it from things). Akses dalam pengertian ini mengandung makna "sekumpulan kekuasaan" (a bundle of powers) berbeda dengan properti yang memandang akses sebagai "sekumpulan hak" (bundle of rights) (Luthfi, 2013). Dalam pengertian akses semacam ini maka kekuasan diartikan sebagai sesuatu yang terdiri atas elemen-elemen material, budaya dan ekonomi-politik yang terhimpun sedemikian rupa membentuk "bundel kekuasaan" (bundle of powers) dan "jaringan kepentingan" (web of powers) yang kemudian menjadi penentu akses ke sumber daya. (Ribot dan Peluso, 2003). Cara melihat akses atas tanah yang beralih dari cara pandang hak (right) menuju kekuasaan (power) dapat menjelaskan proses perolehan tanah untuk kepentingan pasar.

Dalam kerangka pemikiran tersebut, perusahaan biasanya menganggap lahan yang mereka miliki merupakan integrasi dari kedua hak tersebut. Oleh karenanya, pihak perusahaan perkebunan kelapa sawit menganggap mereka memiliki hak untuk membuka dan melebarkan areal penanaman kelapa sawit. Ekspansi lahan yang semakin luas oleh 
perkebunan kelapa sawit pada akhirnya harus mengambil lahan masyarakat sekitar perkebunan. Tidak jarang konflik agraria ini harus berakhir di meja pengadilan. Perusahaan memiliki dasar yang kuat untuk melakukan ekspansi lahan, yaitu, dokumen resmi mengenai luas lahan yang dimiliki perusahaan perkebunan. Sedangakan rakyat, melihat bahwa ekspansi tersebut sebagai pentuk penjajahan atas hak tanah mereka. Apa lagi penguasaan tanah oleh perkebunan sudah merembet kepada tanah ulayat atau tanah adat.

Menurut Syafi'i (2016) tingginya konflik masyarakat dengan perusahaan kelapa sawit menjadi petunjuk bahwa pengelolaan Sumber Daya Alam (SDA) di Indoensia masih sangat buruk. Di samping itu, masalah agraria turut dipengaruhi oleh tumpang tindihnya kewenangan dan kebijakan baik di level pusat maupun daerah. Pasca-pemberlakukan otonomi daerah, terjadi mala-administrasi terkait ijin penggunaan lahan untuk perkebunan kelapa sawit. Mala-administrasi ini berdampak pada pelanggaran hak-hak masyarakat oleh korporasi, seperti penyerobotan lahan masyarakat, kerusakan lingkungan, tidak diberikannya kesempatan perkebunan plasma dikelola oleh masyarakat, dan lain sebaginya (Palupi et al, 2014).

Konflik antara masyarakat dengan perusahaan perkebunan kelapa sawit tidak hanya dilihat dalam kerangka konflik agraria semata. Konflik perebutan lahan dapat dilihat dari kacamata teori komunikasi. Secara sederhana komunikasi dimaknai sebagai proses pertukaran infomasi, simbol, gagasan, ide, dan perasaan antar pihak-pihak yang terlibat dalam setiap proses komunikasi (Dade dan Hassenzahl, 2013). Basis proses komunikasi adalah relasi sosial, yaitu, hubungan antar-anggota dalam sistem masyarakat. Relasi sosial sebagai basis masyarakat dibangun oleh interaksi manusia sebagai anggota dari komunitas (Ellis, 2014). Dalam makna lainnya, relasi sosial lahir dari kesepahaman yang dikonstruksi melalui komunikasi. Kuat atau lemahnya hubungan sosial manusia sangat dipengaruhi oleh komunikasi.

Melalui kerangka komunikasi kita akan sampai pada realitas bahwa konflik merupakan elemen intrinsik dalam hubungan manusia, bahkan bagi banyak orang konflik dianggap sebagai peluang bagi terjadinya perubahan sosial (Viso, 2014). Dalam relasi sosial -sebagai basis komunikasi -konflik dipandang sebagai tajamnya perbedaan pandangan berbagai pihak (Kartikasari, 2000; Littlejohn dan Domenici, 2001). Putnam (2006) menyebutkan bahwa konflik merupakan perjuangan antara kelompok untuk mewujudkan tujuan-tujuan mereka. Tujuan tersebut dapat berupa harga diri, penguasaan aspek ekonomi, status sosial, bahkan identitas (Sen, 2016).

Berdasarkan latar belakang yang telah dikemukakan sebelumnya, tulisan ini berupaya (1) menjelaskan latar belakang terjadinya konflik agraria antara PT. Fajar Baizury \& Brothers dengan masyarakat Desa Cot Mee, Kecamatan Tadu Raya, Kabupaten Nagan Raya; (2) merumuskan strategi komunikasi dalam penyelesaian konflik agraria tersebut. Sejarah perjuangan agraria adalah sejarah perjuangan masyarakat melawan kapitalisme negara dan swasta. Oleh karenanya, perancangan strategi komunikasi yang tepat menjadi salah stau upaya untuk menyelesaikan konflik agraria.

\section{TINJAUAN LITERATUR}

\section{Konflik Agraria dan Perubahan Sosial Masyarakat}

Dalam pandangan disiplin ilmu sosial, konflik dianggap sebagai timpanganya distribusi nilai dan sumber daya, seperti kesejahteraan material kekuasaan, dan prestise serta ketimpangan-ketimpangan lain yang secara sistematik meningkatkan tegangan di antara kelompok-kelompok masyarakat (Poloma, 2013). Pertentangan ini juga dapat bersumber dari identitas yang dimiliki oleh individu atau pun kelompok. Manusia modern -menurut para ekonom -harus mampu memburu kepentingannya sendiri. Mereka menganggap, pola 
tersebut adalah sangat alamiah dan sesuai dengan tuntutan rasionalitas. Namun, pemaksaan atas identitas menjadi "manusia ekonomi" dan "agen rasional" itulah yang membuat konflik terus terjadi dan berkembang (Sen, 2016).

Berangkat dari pemikiran Marx, para teoretikus konflik menolak asumsi Teori Struktural Fungsional dimana konflik dianggap sebagai penghambat dalam perubahan sosial. Sebaliknya, teoritikus konflik mempercayai bahwa konflik adalah bagian integral dari masyarakat yang dengannya perubahan sosial menuju keseimbangan dapat tercapai. Secara umum, konflik menekankan ciri-ciri dinamika internal masyarakat, seperti, (1) distribusi penduduk pada masing-masig strata sosial yang merefleksikan pernedaan akses sumber daya; (2) kepentingan-kepentingan yang saling bertentangan antar-kelompok dan kelas sosial; (3) kemampuan kelompok dominan mempertahankan dominasinya, baik melalui persuasi amupun paksanaan terhadap kelompok lain agar mematuhi aturan dan memenuhi kewajiban-kewajibannya; dan (4) perjuangan kelompok sub-ordinat (termarjinalkan) sebagai stimulus perubahan sosial (Haryanto, 2012).

Dalam kaitannya dengan perubahan sosial, konflik dipandang sebagai elemen intrinsik dalam hubungan manusia (Viso, 2014). Konflik dipandang sebagai akibat dari ketimpangan ekonomi, organisasi politik, dan sistem budaya. Kebanyakan konflik terjadi sebagai dampak dari ketidaksiapan pemerintah dalamm mengatur sistem kehidupan masyarakatnya. Kondisi sosial pasca-konflik menurut Viso (2014) selalu menimbulkan pertumbuhan ekonomi yang lambat, bantuan internasional yang tidak tepat sasaran, serta tidak adanya perhatian terhadap reformasi sosial. Kondisi-kondisi tersebut bisa saja membuat konflik kembali terjadi.

Masyarakat pada hakikatnya merupakan persekutuan yang terkoordinasi secara paksa. Dalam masyarakat selalu terdapat golongan yang saling bertentangan, yaitu, antara penguasa dan yang dikuasai. Masing-masing golongan dipersatukan oleh ikatan kepentingan nyata yang bertentangan secara substansial. Pertentangan tersebut terjadi dalam situasi dimana golongan yang berkuasa berusaha mempertahankan status quo, sedangkan golongan yang dikuasai berusaha untuk mengadakan perubahan-perubahan (Soetomo, 2015). Coser sebagaimana dikutip Poloma (2013) menyatakan bahwa ikatan yang terjadi dalam masyarakat dapat menjadi trigger bagi konflik. Semakin erat hubungan emosional masyarakat, maka akan semakin sulit ketidaksetujuan atas suatu perilaku diungkapkan. Hal ini akan membuat konflik menjadi laten. Masing-masing individu menahan untuk mengungkapkan aspek emosional diri. Sehingga pada titik kulimasi hubungan yang asimetris, konflik akan terbuka lebar dan menjadi lebih dalam.

\section{Komunikasi Strategik Untuk Penyelesaian Konflik}

Komunikasi dimaknai sebagai proses pertukaran informasi, emosional, gagasan, serta ide baik individu maupun kelompok. Komunikasi membutuhkan feedback yang berjalan secara dinamis. Proses komunikasi berlangsung melalui strategi penerjemahan informasi oleh komunikator, mengembangkan pesan, memilih media, mengirim pesan, penerimaan oleh penerima, interpretasi pesan, dan pada akhirnya terjadi umpan balik dari komunikan (Carvalho dan Judy, 2014).

Sebagai basis dalam relasi masyarakat, komunikasi mengandung potensi konflik (Littlejohn dan Domenici, 2001). Sampai saat ini, tidak ada kesepakatan umum dari ilmuan komunikasi terkait dengan definisi konflik. Jika para ilmuan Sosiologi seperti Coser dan Dahrendorf memaknai konflik sebagai pertentangan kelas dan perebutan atas akses terhadap sumber daya yang terbatas (Poloma, 2013), maka komunikasi memandang konflik sebagai pertentangan simbolik. Konflik terjadi sebagai akibat dari perbedaaan persepsi, minat, dan tujuan dari orang-orang yang terlibat dalam komunikasi (Wood, 2009). Komunikasi 
memandang konflik sebagai sebuah arena permainan dan pertarungan. Masing-masing aktor saling berkontestasi untuk memenangkan keinginan.

Dalam buku The Handbook of Communication Science, Berger et al. (2011) membagi konflik dalam dua kategori, yaitu, konflik interpersonal dan konflik antarkelompok. Meski dibedakan, namun terdapat benang merah diantara keduanya. Konflik interpersonal merupakan pertentangan antar-individu. Dalam kaitan ini, kita cenderung berkonflik hanya karena perbedaan pandangan dan interpretasi atas simbol dalam interaksi. Namun, interpretasi dan pandangan tersebut akan berubah seiring dengan perkembangan waktu, apa yang dipahami saat ini mungkin akan berbeda di masa akan datang (Sillars, 2014). Berbeda dengan konflik interpersona,l konflik antar-kelompok melibatkan pertentangan antar kelompok atas perbedaan identitas (Ellis, 2014).

Relasi antar-kelompok mungkin akan berbeda dengan relasi antar-individu. Sifat dan pola konflik yang dihasilkan juga akan berbeda. Proses interpretasi informasi dalam interaksi inter-personal mungkin tidak akan sesulit dalam interaksi antar-kelompok. Sistem jaringan yang ada dalam kelompok membuat konflik akan semakin sulit diselesaikan jika sudah berkembang terlalu jauh. Namun, konflik antar-kelompok dapat diantisipasi jauh sebelum konflik melebar melibatkan seluruh anggota kelompok. Dalam hal inilah strategi komunikasi mendapatkan tempatnya. Strategi komunikasi dimaknai sebagai seperangkat aturan yang harus dijalankan untuk menyampaikan gagasan, informasi, dan pesan guna mencapai tujuan secara efektif.

Konflik agraria dapat dikategorikan sebagai konflik antar-kelompok. Di satu sisi kelompok masyarakat sebagai pihak yang tertindas akibat penyerobotan lahan oleh pihak perusahaan. Sementara di sisi lain perusahaan mewujud menjadi kelompok yang menganggap mereka punya hak atas lahan tersebut. Eskalasi konflik setiap waktu dapat berubah dan berkembang. Ia dapat meluas, namun dapat pula langsung hilang. Namun, hal yang sangat penting adalah bagaimana manajemen konflik dilakukan, serta upaya apa yang dilakukan oleh masing-maisng pihak pasca-konflik.

Dalam upaya manajemen konflik, komunikasi menduduki elemen penting. Bukan hanya sekedar tools, komunikasi dapat menjadi "hati dan jantung" manajemen konflik. Seluruh unsur komunikasi, dapat difungsikan untuk mengelola konflik. Kekeliruan dalam memahami kekuatan dan kelemahan setiap unsur komunikasi, berdampak pada kekeliruan mengatasi konflik. Menurut John Paul Lederach sebagaimana dikutip Viso (2014) bahwa untuk dapat mentransformasikan konflik, maka perlu diperhatikan tiga aspek: aktor yang terlibat, kedalaman dan transformasi konflik, serta kerangka waktu transformasi konflik.

Strategi komunikasi dimaknai sebagai suatu rencana atau rancangan untuk mengubah tingkah laku manusia, dalam skala yang lebih besar melalui transfer ide-ide (Cangara, 2013). Pemahaman akan pentingnya stratgei komunikasi dalam manajemen konflik sangat diperlukan. Strategi komunikasi tidak hanya memperhatikan aspek tahapan perencanaan, namun juga penting untuk membuat tujuan komunikasi terwujud. Untuk mencapai satu tujuan tersebut strategi komunikasi harus dapat menunjukkan bagaimana operasionalnya secara taktis harus dilakukan, dalam arti kata bahwa pendekatan bisa berbeda sewaktu-waktu bergantung dari situasi dan kondisi. Dengan demikian, strategi komunikasi, baik secara makro (planned multi-media strategy) maupun secara mikro (single communication medium strategy) mempunyai fungsi ganda. Pertama, menyebarluaskan pesan komunikasi yang bersifat informatif, persuasif, dan instruktif secara sistematik kepada sasaran untuk memperoleh hasil optimal. Kedua, menjembatani "cultural gap" akibat kemudahan diperolehnya dan kemudahan dioperasionalkannya media massa yang begitu ampuh, yang jika dibiarkan akan merusak nilai-nilai budaya (Jalil, 2014). 
Riset ini menggunakan perspektif Strategic Communication, yaitu, komunikasi terencana yang bermula dan berakhir pada publik (Botan, 2006) dan merupakan aktivitas pokok manajemen (Hallahan et al, 2007). Kajian strategic communication berasal dari disiplin Public Relations yang banyak dipakai oleh perusahaan-perusahaan untuk memahami publik serta meningkatkan positioning mereka di mata publik (Argenti et al, 2005; Plowman, 2011; Plowman dan Wakefield, 2013). Dalam kajian kontemporer, konsep strategic communication banyak digunakan dalam penelitian dan praktik komunikasi organisasi dan komunikasi politik (Manheim, 2011; Pfetsch, 1998).

Dalam aspek praktis, strategic communication banyak digunakan oleh lembagalembaga di bawah naungan PBB dan lembaga donor internasional dalam program pemberdayaan masyarakat di negara berkembang (GTZ, 2006). Kampanye kesehatan dan pencegahan HIV/AIDS misalnya, menggunakan konsep strategic communication sehingga dapat mengubah sikap dan perilaku publik. Hal ini dikarenakan konsep strategic communication yang memungkinkan terbuka komunikasi dua arah, sehingga dapat mendorong masyarakat untuk berpartisipasi.

Dalam aspek konflik, menurut Putnam $(2009 ; 2010)$ strategic communication tidak hanya melahirkan solusi konflik yang bersifat temporal, namun ikut mendorong lahirnya resolusi konflik yang lebih berkesinambungan. Plowman (2011) secara pasti menggunakan strategic communication dalam mengkaji pendekatan yang dilakukan oleh tentara Amerika di Iraq dan Kuwait. Plowman (2011) menemukan bahwa strategic communication memberikan panduan bagi militer untuk mengubah citra buruk ekspansi mereka di Iraq dan Kuwait menjadi lebih positif. Selain itu, strategic communication telah membantu tentara Amerika melaksanakan misi resolusi konflik pasca-perang terbuka dengan tentara dan pemberontak di dua negara tersebut. Riset ini akan menggunakan pendekatan strategic communication yang dikemukakan oleh Silvio Waisbord (2014) yaitu, (1) problem definition; (2) goal selection; (3) strategy junctures; (4) tactics; dan (5) people's motivations for change (Waisbord, 2014). Perspektif strategic communication mendorong mediator fokus pada perencaan tujuan yang terukur, membuat beragam kriteria yang dapat dievaluasi, serta menjalankan setiap strategi yang telah disusun (Plowman, 2011).

\section{METODOLOGI}

Riset ini menggunakan metode kualitatif, yaitu, suatu teknik penelitian yang berupaya memahami fenomena sedalam-dalamnya melalui pengumpulan data sedalamdalamnya (Kriyantono, 2006; Bungin, 2011). Pendekatan yang dipakai dalam penelitian ini adalah studi kasus. Pendekatan studi kasus merupakan rancangan dimana peneliti menggunakan analisis mendalam atas suatu peristiwa (Cresswell, 2014). Melalui studi kasus, peneliti mengumpulkan informasi data berdasarkan waktu yang telah ditentukan (Yin, 2012).

Peneliti melakukan tiga tahap analisis, yaitu, pertama menggali jejak historis konflik agraria antara masyarakat Desa Cot Mee dengan PT. Fajar Baizury \& Brothers. Hal ini bertujuan untuk mengetahui secara mendalam penyebab konflik agraria terjadi di Desa Cot Mee, Kabupaten Nagan Raya. Kedua, peneliti berupaya untuk mengonfirmasi kepada masyarakat terkait gerakan sosial dan relasi antar-aktor yang terlibat dalam perjuangan agraria melawan perusahaan perkebunan kelapa sawit. Ketiga, peneliti juga mengonfirmasi kepada para stakeholder yang berwenang dalam pemberian ijin perkebunan sawit serta menganalisis upaya-upaya yang telah dilakukan untuk menyelesaikan konflik antara masyarakat Desa Cot Mee dengan perusahaan perkebunan PT. Fajar Baizury \& Brothers. 


\section{HASIL PENELITIAN}

\section{Konflik Agraria Desa Cot Mee dan PT. Fajar Baizury \& Brothers}

Desa Cot Mee, Kecamatan Tadu Raya, Kabupaten Nagan Raya telah ada jauh sebelum Indonesia merdeka. Saat itu, sekelompok masyarakat membuka lahan untuk dijadikan tempat tinggal. Bentuk masyaraat yang saat itu masih dalam sistem kerajaan kecil, membuat tanah yang ditempati ditetapkan sebagai tanah adat. Masyarakat berhak menggunakan lahan tersebut untuk berbagia keperluan seperti membangun rumah, berladang, berkebun, dan lain sebagainya. Pasca-kemerdekaan Indonesia, Desa Cot Mee dimasukkan ke dalam wilayah Kabupaten Aceh Barat (Kabupaten Nagan Raya baru terbentuk pada tahun 2002). Dalam pemerintahan yang baru, dikeluarkanlah Surat Hak Guna Usaha (HGU) atas nama PT. Fajar Baizury \& Brothers pada tahun 1991. Perusahaan ini bergerak dalam bidang perkebunan kelapa sawit, mulai dari perkebunan sampai tahap pengolahan menjadi CPO. Sampai tahun 2016, lahan yang dikelola oleh PT. Fajar Baizury \& Brothers seluas 9.600 ha.

Sejak HGU perusahaan perkebunan kepala sawit diberikan, gejala konflik agraria sudah terlihat. Masyarakat mengklaim bahwa lahan yang tercatat dalam HGU merupakan tanah adat yang telah lama mereka kuasai. Atas dasar tersebut, masyarakat menolak pemanfaatan lahan adat tersebut oleh perusahaan. Berbagai upaya penyelesaian konflik dilakukan. Akhirnya disepakati bahwa perusahaan perkebunan kelapa sawit akan menyisakan lahan sebesar 3.000 meter untuk dikelola masyarakat setempat.

Seiring dengan semakin tingginya kebutuhan akan CPO dunia, maka ekspansi luas perkebunan harus dilakukan. Luas lahan perusahaan yang tersisa yang termuat dalam dokumen HGU mulai digarap. Menurut pihak PT. Fajar Baizury, lahan yang mereka garap adalah milik perusahaan. Telah ada sejak dokumen penggunaan lahan dan ijin operasi perusahaan diterbitkan. Namun, di sisi lain masyarakat desa Cot Mee dan Cot Rambong, Kecamatan Tadu Raya, Kabupaten Nagan Raya merasa keberatan dengan upaya ini. Masyarakat menilai bahwa perusahaan perkebunan kelapa sawit telah mengingkari janji dan kesepakatan yang ada sejak tahun 1991.

Pada tanggal 17 Juli 2015 pukul 03.00 WIB, PT. Fajar Baizury \& Brothers mendapati barak-barak pekerja hangus terbakar. Untuk menindaklajuti dan menggali penyebab kebarakan sebenarnya, pihak perusahaan melaporkan kejadian tersebut ke pihak Polres Nagan Raya. Tidak menunggu waktu lama, polisi telah dapat mengidentifikasi terduga pelaku pembakaran barak pekerja perkebunan. Mereka adalah Asubki, Musilan, Julinaidi dan Khaidir. Empat warga Desa Cot Mee, Kecamatan Tadu Raya, Kabupaten Nagan Raya. Mereka adalah tokoh masyarakat dan pemuda setempat yang selama ini aktif dalam perjuangan melawan penyerobotan lahan rakyat yang diduga dilakukan oleh PT. Fajar Baizury \& Brothers.

Setelah melakukan penyelidikan, ke-empat terduga ditetapkan menjadi tersangka. Semua berkas hasil penyelidikan dilimpahkan penyidik polisi ke Kejaksaan Negeri Meulaboh. Tidak perlu lama, ke-empat tersangka pembakaran barak perkebunan PT. Fajar Baizury \& Brothers telah duduk di depan majelis hakim Pengadilan Negeri Meulaboh. Keempat tersangka terancam tindak pidana pembakaran dan pengrusakan Pasal 187 ayat (1) Jo Pasal 406 Jo Pasal 55 ayat (1) KUHPidana dengan ancaman maksimal 12 tahun penjara.

Penetapan empat warga Cot Mee sebagai tersangka pembakaran barak milik PT. Fajar Baizury \& Brothers seketika mendapat respon dari masyarakat. Masyarakat melakukan protes atas penetapan tersebut. Mereka menganggap empat warganya tidak bersalah dan kasus ini adalah sebuah bentuk kriminalisasi dari perusahaan. Beberapa aksi unjuk rasa digelar oleh masyarakat. Setiap persidangan empat tersangka selalu dihiasi oleh demonstrasi 
masyarakat Desa Cot Mee. Mereka meminta pihak pengadilan membebaskan empat warga mereka dari jeratan hukum.

Menurut Herman, Koordinator LBH Banda Aceh Pos Meulaboh, penetapan empat tersangka ini terkesan dipaksakan. Penetapan status tersangka dilakukan kepolisian tanpa proses pemanggilan empat warga sebagai saksi. Herman mencurigai ini merupakan rentetan dan ekses dari akar persoalan konflik lahan antara masyarakat dengan pihak perusahaan telah bertahun-tahun yang tidak kunjung terselesaikan, bagaimana tidak hal ini jelas dimana keempat warga cot mee tersebut juga berperan dalam hal aksi memperjuangkan tanah ulayat milik desa Cot Mee yang diduga diserobot pihak PT. Fajar Baizury \& Brothers.

Sengketa lahan antara PT. Fajar Baizury \& Brothers dengan masyarakat Desa Cot Mee, Kecamatan Tadu Raya, Kabupaten Nagan Raya telah berlangsung sejak lama. Konflik lahan paling baru terjadi setelah diketahui pihak PT. Fajar Baizury \& Brothers melakukan penyerobotan lahan masyarakat. Merespon penyorobotan sewenang-wenang ini, masyarakat Desa Cot Mee melakukan protes. Proses dialog dengan pihak perusahaan tidak membuahkan hasil. Warga melanjutkan aksi unjuk rasa dan pemblokiran akses ke perkebunan kelapa sawit. Kondisi adalah ancaman bagi perusahaan. Jika akses ke perkebunan di blokir oleh warga, maka operasional perusahaan akan terganggu. Target CPO harian tidak dapat tercapai.

Buntunya proses pencarian solusi bagi sengketa lahan masyarakat Desa Cot Mee dengan PT. Fajar Baizury \& Brothers telah memperburuk hubungan masyarakat dengan perusahaan. Masyarakat yang selama ini hidup berdampingan dengan perusahaan bahkan dapat mengambil keuntungan dari penjualan hasil sawit dari perkebunan warga, menjadi tidak lagi harmonis. Masyarakat menilai, lebih 400 hektar lahan yang diklaim oleh perusahaan sebagai wilayah HGU adalah milik masyarakat Desa Cot Mee. Perusahaan tidak berhasil menunjukan bukti tertulis yang menguatkan bahwa lahan tersebut adalah sah milik PT. Fajar Baizury \& Brothers.

Di tengah konflik yang meruncing, perusahaan terus melakukan produksi pada lahan sengketa. Hal ini semakin menambah keruh suasana. Pemerintah Kabupaten Nagan Raya diminta untuk turun tangan menyelesaikan. Namun, di tengah proses penyelesaian ini Pemerintah Kabupaten Nagan Raya menerbitkan Surat Keputusan Bupati Nomor 591/17/2016. Surat keputusan yang diterbitkan tanggal 29 Januari 2016 tersebut berisikan pemberian kewenangan kepada PT. Fajar Baizury \& Brothers untuk menggarap lahan seluas 650 hektar. Masyarakat Desa Cot Mee lantas memberontak. Mereka menganggap lahan yang diserahkan Bupati Nagan Raya adalah milik masyarakat.

Pemerintah Nagan Raya dituding telah mengkhianati masyarakat Desa Cot Mee dengan menerbitkan Surat Keputusan Bupati secara diam-diam. Akibatnya, konflik lahan antara masyarkat Desa Cot Mee dengan PT. Fajar Baizury \& Brothers yang sudah berlangsung sejak lama semakin melebar. Menurut Asubki, salah satu warga Desa Cot Mee yang getol melakukan perlawanan terhadap kesewenang-wenangan penyerobotan lahan oleh PT. Fajar Baizury \& Brothers, kebijakan Pemerintah Kabupaten Nagan Raya sangat berbahaya. Hal ini dikarenakan kebijakan tersebut dapat menciptakan konflik baru antara masyarakat dengan perusahaan (lintasnasional.com, 29/3/2016).

Melihat kondisi konflik lahan yang semakin berkembang, Pemerintah Kabupaten Nagan Raya melalui Kepala Dinas Perkebunan dan Kehutanan telah menyurati PT. Fajar Baizury \& Brothers. Surat bernomor 525/375/III/2016 tertanggal 12 Maret 2016 menginstruksikan agar perusahaan sawit segera menyelesaikan kasus sengketa lahan dengan masyarakat Cot Mee. Upaya ini diambil oleh Pemerintah Kabupaten Nagan Raya untuk merespon tuntutan masyarakat agar pemerintah daerah mengambil langkah konkrit sehingga konflik tidak berlarut. 
Beragam upaya pun juga telah dilakukan, baik melalui mediasi dari pemerintah daerah maupun melalui forum-forum yang membahas permasalahan konflik agraria di Aceh. Dalam upaya penyelesaian sengketa ini, PT. Fajar Baizury \& Brothers bersedia melakukan ganti rugi lahan masyarakat sebesar Rp 3 juta. Namun, masyarakat menolak tawaran tersebut dan mempertahakan hak atas tanah mereka. Menurut Muhammad Hamzah, Ketua Tuha Peut Desa Cot Mee, penolakan ganti rugi ini karena tidak sesuai dengan kesepakatan awal. Dalam kesepakatan sebelumnya, kata Muhammad Hamzah, warga meminta perusahaan agar membayar harga tanah sesuai standar pasaran. Di samping itu, PT. Fajar Baizury \& Brothers juga belum memenuhi kewajibannya membangun kebun plasma, maka warga memutuskan 314 hektar tanah mereka agar di bangun kebun plasma sesuai aturan yang ditetapkan pemerintah. Akibat perusahaan ingkar, maka warga memutuskan untuk mempertahankan tanahnya.

Sampai saat ini, konflik agraria antara masyarakat desa Cot Mee dengan PT. Fajar Baizury \& Brothers masih terus belangsung. Perjuangan masyarakat untuk mempertahankan hak mereka atas tanah ulayat masih terus diperjuangkan. Pada awal bulan Mareet 2017 masyararakat Cot Mee memasang patok tanah untuk menegaskan batas antara tanah masyarakat dengan HGU perusahaan. Setidaknya sudah empat patok tanah yang dipasang masyarakat. Sementara itu, titik konflik telah sampai pada tahap yang mengerikan. Kasus terakhir masyarakat mendapatkan teror dari orang tak dikenal (OTK). Teror ini dilakukan via telepon untuk mengancam aktor-aktor yang selama ini menggerakkan masyarakat untuk berjuang mempertahankan hak tanah mereka. Teror terberat adalah penculikan yang dicurigai masyarakat dilakukan oleh orang suruhan perusahaan sawit. Tujuan dari ancaman dan teror ini adalah untuk melemahkan semangat perjuangan agraria yang sudah dua tahun terakhir dilakukan oleh masyatkat. Untuk kasus teror ini sendiri sudah dilaporkan masyarakat ke pihak kepolisian setempat.

\section{Pembahasan}

Konflik agraria tidak dapat dilepaskan dari hubungan-hubungan sosial yang berkaitan dengan pengontrolan dan penggunaan sumber-sumber agraria (Afrizal, 2006). Perlawanan masyarakat sebagai aksi kolektif karena kesadaran masyarakat atas kondisi ketertindasan kondisi hidup mereka sebagai akibat penggunaan dan penyalahgunaan kekuasaan pihak pemegang kuasa-kuasa ekonomi-politik (Fauzi, 2008). Secara lebih ekstrim Maladi (2012) menyebutkan bahwa konflik agraria yang sering terjadi membuktikan bahwa pemerintah belum mampu memberikan perlindungan hukum secara maksimal kepada rakyat.Bahkan jika ditelusuri lebih jauh, kasus konflik selama ini berawal dari adanya dominasi persoalan struktural. Seharusnya, pemerintah menjalankan hukum sebagai law as facilitation of human interaction untuk memenuhi keinginan rakyatnya (Maladi, 2012).

Aceh merupakan salah satu daerah yang memiliki lahan perkebunan kelapa sawit yang luas. Lahan-lahan tersebut sebagian besar dikuasai oleh perusahaan/korporasi. Menurut data Badan Pusat Statistik (BPS Provinsi Aceh tahun 2013, jumlah total luas perkebunan kelapa sawit di Aceh adalah 198.246 ha dengan jumlah produksi 355.366 ton (BPS Aceh, 2015). Jumlah tersebut terus meningkat setiap tahunnya. Sampai tahun 2016, jumlah luas lahan dan total produksi kelapa sawit di Aceh berturut-turut sebesar 462.010 ha dan 1.146.793 ton (Dirjen Perkebunan, 2016). Dalam jumlah tersebut, Kabupaten Nagan Raya menempati urutan pertama jumlah lahan kelapa sawit baik yang dimiliki oleh korporasi maupun perkebunan rakyat. 
Tabel 1 Luas Lahan dan Total Produksi Perkebunan Kelapa Sawit Per Kabupaten/Kota di Provinsi Aceh

\begin{tabular}{cl} 
No. & \multicolumn{1}{c}{ Kabupaten/Kota } \\
1 & Nagan Raya \\
2 & Aceh Singkil \\
3 & Aceh Tamiang \\
4 & Aceh Timur \\
5 & Aceh Barat Daya \\
6 & Subulussalam
\end{tabular}

Luas Lahan (ha) ${ }^{* *}$

40.216

21.602

20.145

19.854

17.200

15.593
Total Produksi (ton) ${ }^{* *}$

73.523

63.681

40.920

26.891

14.215

28.541

Sumber: BPS Aceh, 2015

*beberapa kabupaten/kota tidak semua data ditampilkan

*** data per tahun 2013

Masyarakat dan pemerintah daerah di Aceh saat ini memiliki pandangan bahwa kelapa sawit menyumbang peningkatan kesejahteraan rumah tangga. Oleh karenanya, banyak dilaukan alih fungsi lahan menjadi perkebunan kelapa sawit. Pemerintah memandang bahwa keberadaan perkebunan kelapa sawit dapat meningkatkan Pendapatan Asli Daerah (PAD) dari pajak yang dibayarkan oleh perusahaan sawit. Oleh karenanya, pemerintah daerah sering mudah mengeluarkan ijin operasional perkebunan kelapa sawit kepada korporasi. Ijin operasional inilah yang kemudian menjadi permasalahan dan sumber konflik di kemudian hari.

Di era reformasi, konflik agraria di Indonesia semakin meningkat jumlahnya terlebih mulai munculnya gerakan reclaiming petani atas tanah yang selama ini dikuasai oleh swasta dan negara. Gerakan perlawanan masyarakat atas tanah ini tidak jarang berbuntut pada kekerasan sebagai upaya penyelesaiannya (Astuti, 2011). Menurut data Konsorsium Pembaruan Agraria sampai tahun 2016 setidaknya terjadi 450 konflik lahan dengan luasan wilayah 1.265.027 hektar dan melibatkan 86.746 KK yang tersebar di seluruh Indonesia. Angka ini meningkat dua kali lipat dari tahun sebelumnya (2015) dimana hanya ada sekitar 252 konflik agraria. Ini adalah kondisi yang sangat membuat miris. Jika diambil rata-ratanya, setidaknya setiap hari masyarakat harus kehilangan 7.756 hektar lahan akibat konflik (KPA, 2016).

Konflik agraria saat justru terjadi di tengah pemerintah gencar meningkatkan kesejahteraan perekonomian masyarakat. Tidak dapat dipungkiri bahwa konflik agraria di era reformasi didominasi oleh konfllik antara rakyat dengan perusahaan. Beberapa perusahaan -khususunya perusahaan perkebunan -merupakan warisan pemerintah Orde Baru yang menerbitkan ijin eksplorasi dan eksploitasi lahan. Penggunaan Hak Guna Usaha (HGU) perkebunan yang tidak sesuai dengan aturan ikut menyumbang semakin tajamnya konflik agaria ini. Undang-Undang Nomor 5 tahun 1960 tentang Peraturan Dasar PokokPokok Agraria, merupakan strategi negara untuk menguasai tanah demi kemakmuran rakyat sesuai dengan amanah Pasal 33 UUD 1945. Namun, UU Pokok Agraria justru tidak mampu menahan laju konflik agraria. Beberapa produk perundang-undangan lainnya terkesan "mengebiri" UUPA sehingga konflik agraria tidak dapat dielakkan Lusiana, 2007; Maladi, 2012). 
Grafik 1 Jumlah Konflik Agraria di Indonesia Tahun 2009-2016

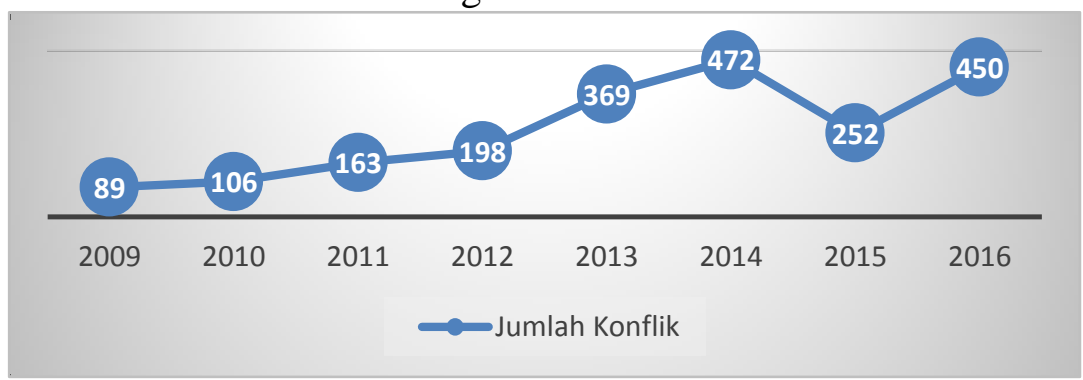

Sumber: diolah dari laporan tahunan KPA tahun 2009-2014; 2015; dan 2016.

Konflik agraria tertinggi disumbang oleh ekspansi perusahaan sawit. Banyaknya perusahaan sawit yang beroperasi di Indonesia sebenarnya menjadi peluang bagi peningkatakan ekonomi negara. Pada akhirnya ikut meningkatkan perekonomian masyarakat. Hal ini sejalan dengan teori trickle down effect dimana peningkatan pertumbuhan ekonomi negara akan berdampak nyata pada meningkatnya ekonomi masyarakat. Namun, ternyata kondisi ini tidak sepenuhnya berhasil. Realitas di lapangan memperlihatkan ekspansi besar-besaran perusahaan sawit telah menimbulkan bencana ekologi dan bencana sosial.

Ditinjau dari aktor yang terlibat, perusahaan perkebunan masih menempati urutan pertama dalam konflik agraria. Berdasarkan laporan KPA (2016) sekitar 163 kasus melibatkan masyarakat berhadapan dengan perkebunan. Kondisi ini menjadi indikator bahwa perluasan lahan perkebunan masih menjadi ancaman bagi pembaruan agraria di tanah air. Salah satu komoditas yang patut diperhatikan adalah ekspansi perkebunan sawit yang telah banyak melahirkan konflik agraria di beberapa wilayah Indonesia. Menurut Widiyanto et al (2012) terdapat empat tipologi aktor-aktor yang terlibat dalam konflik agraria di Indonesia, yaitu, (1) masyarakat adat vs perusahaan; (2) komunitas lokal vs Perhutani; (3) petani vs perusahaan; dan (4) komunitas lokal vs perusahaan/korporasi. Dari ke-empat tipologi aktor konflik tersebut, komunitas lokal vs perusahaan/korporasi merupakan jumlah terbanyak terkait aktor konflik yang terlibat. Hal ini terjadi karena perbedaan dasar klaim para pihak yang menyebabkan tumpang tindih klaim atas tanah yang disengketakan. Perusahaan memegang klaim formal berdasarkan ijin usaha (HGU) sedangkan masyarakat hanya memegang klaim historis yang cenderung non-formal sehingga selalu kalah dalam setiap persidangan.

Hasil riset Colchester et al (2007) mendapati bahwa perusahaan perkebunan sawit menipu masyarakat. Perusahaan biasanya membujuk masyarakat agar mau menyerahkan tanah mereka dengan berbagai kesepakatan, seperti pembukaan kebun plasma masyarakat. Akan tetapi pada praktiknya berbeda. Program yang dijanjikan tidak diberikan. Suara-suara masyarakat juga tidak dilibatkan dalam pengambilan keputusan terkait tanah mereka. Korporasi bersekongkol dengan pemerintah daerah untuk melahirkan kebijakan prokorporasi dan membujuk masyarakat untuk pergi dari tanah mereka. Perlakuan ini sama dengan bentuk mencabut nilai-nilai tradisional dari komunitas adat (Potter dan Lee, 1998).

Bencana ekologi terjadi karena pembukaan lahan yang dilakukan oleh perusahaan sawit berdampak pada kerusakan lingkungan ekologis, seperti penebangan hutan, tergesernya habitat fauna sekitar hutan, kekeringan, dan lain-lain. Di samping itu, limbah buangan sawit juga menjadi permasalahan ekologis lainnya. Dalam observasi yang penulis lakukan, pihak perusahaan sawit di Nagan Raya membuang limbah kering sawit di pinggir jalan. Limbah ini menimbulkan bau busuk, bahkan terindikasi berdampak buruk bagi pernafasan. Inilah kondisi realitas di lapangan terkait keberadaan perusahaan sawit di Aceh. 
Di samping itu bencana sosial terjadi akibat pembukaan luas lahan oleh perusahaan yang mengundang konflik dengan masyarakat. Hal ini terjadi disebabkan oleh beberapa hal, yaitu, penyerobotan lahan masyarakat oleh perusahaan, keengganan perusahaan untuk menerapkan kebun inti plasma di masyarakat sekitar, pola perekrutan tenaga kerja yang tidak memperhatikan masyarakat sekitar perusahaan, serta timpangnya peruntukan dana corporate social responsibility (CSR) perusahaan.

Untuk konteks Aceh, konflik agraria telah terjadi sejak tahun 1990. Kebanyakan kasus tersebut sampai saat ini masih terus berlanjut tanpa penyelesaian, seperti, konflik antara PT. Kalista Alam dengan masyarakat Dusun Melati Gampong Krueng Seumanyam, Kelompok Tani Makmue Mulia, Desa Geulanggang Gajah dan Kaye Unoe dengan PT. Surya Panen Subur, serta PT. Nafasindo dengan masyarakat Singkil. Sampai saat ini, konflik terus berlangsung bahkan melibatkan lebih banyak perusahaan. Perusahaan sawit melakukan monopoli secara besar-besaran. Menurut Konsorsium Pembaharuan Agraria (2016) kondisi ini merupakan dampak dari kebijakan perkebunan sebelum Putusan MK 138/PII-XIII/2015 dimana korporasi perkebunan sawit diberikan karpet merah untuk beroperasi tanpa HGU, hanya bermodalkan ijin lokasi serta alokasi 20 persen untuk kebun plasma yang diinterpretasikan berada di luar areal HGU (KPA, 2016).

Tabel 2 Konflik Agraria Perkebunan Sawit di Aceh
Perusahaan Sawit

$\begin{array}{cr}\text { No } & \text { Lokasi } \\ 1 & \text { Nagan Raya }\end{array}$

2 Aceh Barat

$\begin{array}{ll}3 & \text { Aceh Singkil } \\ 4 & \text { Aceh Tamiang } \\ 5 & \text { Bireuen } \\ 6 & \text { Aceh Besar }\end{array}$

7 Aceh Barat Daya

8 Aceh Tenggara
PT. Surya Panen Subur

PT. Kalista Alam

PT. Agro Sinergi Nusantara

PT. Fajar Baizury \& Brothers

PT. Wiratako Meulaboh

PT. Agro Sinergi Nusantara

PT. Ubertraco/Nafasindo

PT. Rapala

PT. Syaukat Sejahtera

Pengelola Tahura Pocut Meurah

Intan

PT. Dua Perkasa Lestari

Pengelola Taman Gunung Leuser
Darul Makmur

Tadu Raya

Kuala Pesisir

Desa Teumarom

Desa Jawi

Desa Lueng Baroe

Singkil

Aceh Tamiang

Juli

Lamtamot

Babahrot

Ketambe

Sumber: Data penelitian, 2017.

Konflik agraria yang terjadi antara masyarakat Desa Cot Mee dengan PT. Fajar Baizury bukanlah konflik yang baru muncul. Berlarutnya konflik ini sebagai akumulasi dari konflik yang belum diselesaikan di masa lalu. Di samping keterlibatan pemerintah dalam pemberian izin bagi operasional perusahaan serta kurangnya monitoring dan evaluasi terhadap aktivitas perusahaan. Pemerintah Kabupaten Nagan Raya beru bertindak ketika gejala konflik sudah muncul kepermukaan. Dalam kondisi ini, konflik yang sudah mengemuka akan sangat sulit diselesaikan mengingat dua kepentingan yang saling berkontestasi. Pemerintah Kabupaten Nagan Raya secara normatif telah melakukan langkahlangkah penyelesaian melalui mediasi sejak tahun 2013. Melalui surat Bupati Nagan Raya yang ditujukan kepada Pimpinan PT. Fajar Baizury, Pemkab Nagan Raya meminta agar PT. Fajar Baizury menghentikan aktivitas pembukaan lahan yang menyerobot tanah masyarakat Cot Mee. Namun, upaya mediasi ini selalu mengalami kebuntuan. Konflik terus berkembang sampai saat ini. Bahkan empat orang masyarakat Desa Cot Mee ditangkap dan dijatuhkan 
hukuman penjara karena terbukti bersalah membakar barak milik PT. Fajar Baizury \& Brothers.

Melihat eskalasi konflik yang terus membesar, maka dibutuhkan solusi untuk menekan munculnya konflik terbuka yang lebih parah. Salah satu pendekatan yang dapat diambil adalah melalui perumusan strategi komunikasi. Hal ini berguna beik untuk perusahaan sawit, masyarakat, maupun pemerintah daerah Kabupaten Nagan Raya. Meskipun Pemkab Nagan Raya telah mengistruksikan agar PT. Fajar Baizury \& Brothers segera menyelesaikan konflik dengan masyarakat Cot Mee, namun instruksi tersebut tidak membeberkan secara gamblang akan strategi penyelesaian yang harus dilakukan. Di samping itu, instruksi tersebut terkesan upaya lepas tangan Pemkab Nagan Raya, dimana seharusnya Pemkab adalah pihak mediator yang perlu membantu mencari solusi. Bukan hanya diserahkan pada PT. Fajar Baizury dan masyarakat, jika hal ini dilakukan maka tidak akan sampai pada titik temu.

Konstruksi perusahaan perkebunan dan masyarakat terhadap tanah konflik tersebut berbeda. PT. Fajar Baizury \& Brothers tetap bersikukuh bahwa mereka memiliki hak atas tanah seluas 640 hektar (termasuk 300 ha di Desa Cot Mee). Hal ini didasarkan atas klaim formal, yaitu, dokumen HGU yang mereka punya. Oleh karenanya perluasan lahan perkebunan layak untuk dilakukan. Di sisi lain, masyarakat menilai dokumen yang dimiliki oleh PT. Fajar Baizury \& Brothers tidak sah karena masyarakat masih memiliki sertifikat tanah yang sah. Dua konstruksi pemikiran ini sangat sulit disatukan jika penyelesaian hanya diserahkan kepada pihak perusahaan dan masyarakat. Alih-alih konflik dapat diselesaikan, hal yang paling buruk bisa saja terjadi, yaitu, konflik terbuka dengan intensitas yang sangat tinggi.

Dalam upaya menyelesaikan konflik secara berkesinambungan, penting kiranya memanfaatkan aspek Komunikasi Strategis (Strategic Communication). Aspek komunikasi strategis berkaitan dengan bagaimana seluruh aktor yang terlibat dalam konflik dapat memaksimalkan pencapaian penyelesaian konflik agraria (Waisbord, 2014). Perspektif ini lebih mengedepankan aspek partisiparoti antar-aktor yang terlibat dalam konflik. Selama ini penyelesaian konflik cenderung mengikuti selera para elite politik yang kadang tidak serta merta memahami duduk permasalahan yang ada. Oleh karenanya, melalui komunikasi strategis, masyarakat diberikan ruang yang luas untuk merumuskan jalan keluar bagi permasalahan yang ada. Pemerintah hanya berfungsi sebagai fasilitator dan mediator jika ternyata dalam upaya penyelesaian justru mengalami jalan buntu.

Berdasarkan hasil analisis, terdapat lima tahapan yang dapat dipakai sebagai upaya penyelesaian konflik agraria antara masyarakat Desa Cot Mee dengan PT. Fajar Baizury \& Brothers. Kelima tahapan tersebut, yaitu, pertama, mendefinisikan masalah. Selama ini antar-pihak cenderung melihat tanah yang disengketakan dalam perspektif mereka masingmasing. Hal ini menyulitkan penyelesaian. Perspektif individu cenderung menjebak dan keliru karena akan menyebabkan bias dan memunculkan steterotip. Dalam upaya mediasi, harusnya seluruh aktor mendefinisikan masalah secara bersama. Hal ini akan membawa pemahaman yang lebih terukur dan tepat untuk melihat penyebab masalah (Waisbord, 2014).

Kedua, memilih tujuan (goal selection). Konflik agraria merupakan konflik yang kompleks karena berkaitan dengan hak kepemilikan dan sekelumit aturan hukum yang saling bertabrakan. Pemilihan tujuan merupakan proses sangat politis. Masyarakat, perusahaan, dan pemerintah daerah perlu menyatukan persepsi terkait tujuan akhir yang diharapkan. Ketiga, strategic junctures. Tujuan-tujuan strategis tidak berada dalam ruang hampa udara. Namun, beradap dalam ruang-ruang yang dipengaruhi oleh kondisi masyarakat, komunikasi, dan gerakan sosial masyarakat. Strategy junctures mengharuskan madiator untuk memahami kondisi masa lalu para pihak yang bertikai. Banyak kejadian konflik masa kini yang tidak 
dapat dilepaskan dari akar masalahnya di masa lalu. Jebakan "masa lalu" ini terkadang membuat konflik sulit diselesaikan. Proses perubahan pengetahuan, sikap, dan perilaku para aktor konflik ditentukan oleh kondisi-kondisi yang mereka alami di masa lalu. Keinginan antar-aktor tentu sangat berbeda dan terus berdinamika selama proses penyelesaian konflik. Dalam hal inilah peran mediator harus memainkan strategis secara cerdas untuk menekan kedua belah pihak agar mau menyatukan persepsi dan kembali pada tujuan yang telah disepakati (Littlejohn dan Domenici, 2007; Waisbord, 2014).

Ke-empat, taktik (tactics). Proses ini mendorong masing-masing aktor untuk memilih dan menggunakan kerangka pikir yang sama untuk mencapai tujuan. Manheim (2011) menyatakan bahwa taktik secara umum berkaitan dengan kampanye yang diorganisasikan dan dijalankan oleh lembaga-lembaga politik, ekonomi, dan kelompok sosial untuk mencapai beragam tujuan. Dalam hal penyelesaian konflik agraria, taktik dapat dijalankan melalui pemanfaatan media. Tidak dapat dipungkiri, media memiliki pengaruh besar terhadap konflik (Gilboa, 2009). Besar atau kecilnya suatu konflik dipengaruhi oleh framing media (McQuail, 2011; Severin dan Tankard, 2011). Paparan berita media selama konflik agraria antara masyarakat Desa Cot Mee dengan PT. Fajar Baizury berfokus pada masalah (event) tanpa merekomendasikan penyelesaian. Selain itu, antar-aktor mengeluarkan pernyataan yang tidak pada substansi penyelesaian melainkan saling menyalahkan. Jika hal ini dibiarkan, maka tujuan dan upaya penyelesaian konflik yang bertahun-tahun dilakukan akan menemukan titik buntu.

Selain penggunan media massa, dapat pula digunakan taktik pendekatan jaringan sosial (social network). Jaringan merupakan modal sosial masyarakat pedesaan yang biasanya berpengaruh terhadap muncul dan berkembangnya aksi kolektif (Gilchrist, 2009). Gerakan masyarakat melawan penyerobotan tanah oleh perusahaan dibentuk oleh sebuah pola jaringan yang saling mempengaruhi. Struktur jaringan yang terbentuk biasanya tidaklah mengikuti struktur formal. Dalam gerakan masyarakat Desa Cot Mee, jaringan terbentuk melalui komunikasi yang intensif oleh aktor-aktor sentral, seperti, aktivis lingkungan, aktivis bantuan hukum, aktivis mahasiswa, dan tokoh-tokoh masyarakat. Pemetaan jaringan sosial akan memudahkan mediator untuk mengetahui siapa saja aktor sentral yang mempengaruhi masyarakat. Dengan mengetahui aktor sentral dan kekuatannya, maka taktik persuasif dapat dilakukan.

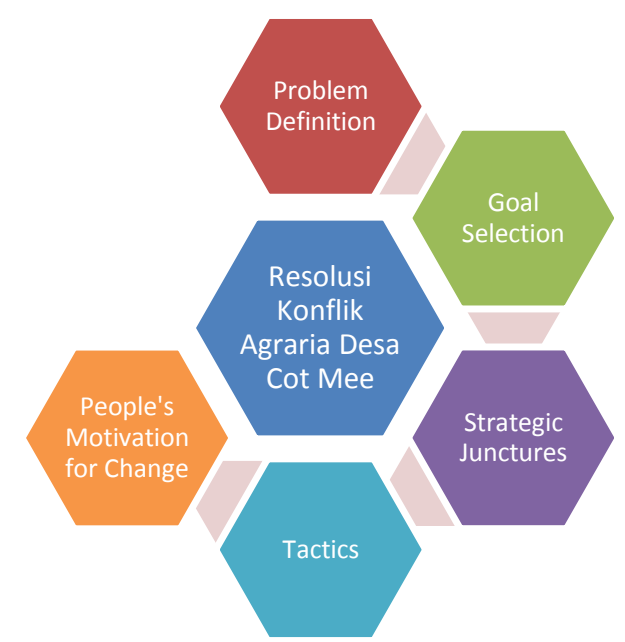

Gambar 1 Komunikasi Strategik Penyelesaian Konflik Agraria

Kelima, keinginan masyarakat untuk berubah (people's motivations for change). Motivasi berkaitan dengan internal diri individu. Tidak dapat dipungkiri, dalam setiap 
konflik motivasi yang mendasari cenderung berbeda-beda. Motivasi yang berbeda ini dipertemukan oleh sebuah kepentingan yang dikonstruksi sebagai perjuangan rakyat membela hak asasi mereka. Berlarutnya konflik dipengaruhi oleh kegagalan mediator memahami motivasi masyarakat. Di samping itu, Pemerintah Kabupaten Nagan Raya sebagai mediator tidak menggunakan strategi yang konkrit untuk mengubah sikap dan perilaku antar-aktor. Oleh karenanya, masing-masing aktor masih tetap mengedepankan tujuan dari motivasi diri untuk mempertahankan tanah yang dianggap milik mereka.

Merespon kondisi ini, selayaknyalah Pemkab Nagan Raya mengatur strategi untuk menyelesaikan konflik agraria ini. Upaya ini dapat dilakukan dengan melibatkan berbagai stakeholders yang ada, seperti, Badan Pertanahan Nasional, Majelis Permusyawaratan Ulama (MPU) Nagan Raya, TNI/Polri, dan Lembaga Bantuan Hukum. Selain itu, pelibatan akademisi dalam penyelesaian konflik agraria ini juga perlu dikukan. Hal ini dibutuhkan untuk keperluan dukungan riset bagi upaya penyelesaian konflik. Data-data hasil riset akademisi perlu untuk menjadi dasar dalam menyusun stragegi komunikasi penyelesaian konflik agraria.

Beberapa strategi komunikasi yang dapat dilakukan adalah (1) melakukan konsolidasi internal terkait dengan proses penyelesaian sengketa; (2) melakukan mediasi dengan melibatkan berbagai pihak yang terlibat konflik; dan (3) melibatkan stakeholders dalam penyelesaian konflik. Upaya konsolidasi pihak internal -khususnya Pemkab Nagan Raya -merupakan strategi yang penting dilakukan. Melalui konsolidasi ini, pemerintah dapat memetakan asal mula konflik, pihak yang terlibat, jumlah kerugian, serta strategi penyelesaian. Konsolidasi merupakan proses komunikasi, dimana semua pihak terlibat dalam intensitas diskusi yang tinggi.

Proses mediasi juga merupakan bagian dari strategi komunikasi dalam penyelesaian konflik agraria. Pemkab Nagan Raya perlu memposisikan dirinya sebagai mediator. Peran mediator sebagai pihak yang memediasi antara dua belah pihak yang berkonflik. Sebagai mediator sudah seharusnya menaati aturan-aturan dalam resolusi konflik. Seperti dikemukakan oleh Kymlicka dan Bashir (2008) bahwa proses mediasi konflik antara dua pihak diperlukan pendekatan permusyawaratan dan pemufakatan. Dalam konteks ini mediator perlu memahami kondisi real dari masalah. Mediator tidak perlu memihak pada salah satu aktor, melainkan berpihak pada kebenaran. Semua data yang telah dikumpulkan dalam proses konsolidasi harusnya dibuka dan diperlihatkan kepada pihak-pihak yang berkonflik. Sehingga didapatkan jalan keluar yang sesuai dengan kebenaran.

Proses ketiga adalah pelibatan stakeholders. Seperti yang telah dikemukakan sebelumnya, bahwa peran stakeholders menjadi urgen dalam penyelesaian konflik. Akan tetapi perlu pula disadari bahwa tidak semua stakeholders perlu dilibatkan. Pelibatan stakeholders harus berpijak pada efektifitas dan efisiensi penyelesaian sengketa. Masingmasing stakeholeders yang terlibat memiliki kapasitas dan kompetensi dalam penyelesaian konflik, baik secara hukum, kebijakan, budaya, sosial, dan agama. Hal ini penting dipertimbangkan karena masyarakat Aceh adalah masyarakat yang religius, sehingga pendekatan agama bisa menjadi jalan keluar bagi penyelesaian konflik.

\section{Kesimpulan dan Saran}

Konflik agraria telah menjadi permasalahan utama di Indonesia. Konflik agraria justru terjadi dalam semangat reformasi agraria yang mengembalikan hak masyarakat dan adat untuk menguasai dan memanfaatkan tanah dan lahan demi kesejahteraan mereka. Konflik agraria didominasi oleh konflik antara masyarakat adat dengan perusahaan/korporasi. Jika ditinjau lebih teliti, konflik disebabkan oleh (1) ekspansi lahan kelapa sawit yang berakibat penyerobotan tanah masyarakat dan adat; (2) tumpang tindihnya 
regulasi dan kebijakan ijin penggunaan lahan perkebunan kelapa sawit; dan (3) kontestasi klaim antara masyarakat dan perusahaan perkebunan (tradisional-historis $v s$ juridis-formal). Kondisi-kondisi tersebut telah lama berlangsung, namun sampai saat ini belum ditemukan upaya strategis yang berkelanjutan untuk menyelesaikannya.

Akar permasalahan agraria antara masyarakat Desa Cot Mee dengan PT. Fajar Baizury \& Brothers sama dengan akar konflik agraria secara umum. Dalam upaya penyelesaian konflik yang berkesinambungan, perpsektif Communication Strategic dapat dipakai karena merinci beragam strategi penyelesaian konflik. Perspektif Comunication Strategic memiliki lima elemen, yaitu, (1) problem definition; (2) Goal Selection; (3) Strategic Junctures; (4) Tactics; dan (5) people's motivations for change. Kelima elemen ini terkait erat dengan model partisipatori yang dianggap cukup ideal dalam dimenasi perubahan sosial. Realitas konflik agraria ini telah mendorong agar segera disahkannya Qanun Pertanahan Aceh. Sudah selama 10 tahun sejak 2006, Qanun Pertanahan Aceh hanya berbentuk rancangan oleh karena belum adanya payung hukum setingkat Peraturan Presiden dan Peraturan Menteri Agraria dan Tata Ruang. Qanun ini berfungsi sebagai jalan keluar bagi penyelesaian berbagai konflik agraria yang ada di Aceh.

Untuk menciptakan kesinambungan resolusi konflik tanah antara masyarakat dengan korporasi, penting untuk melakukan program pemberdayaan kepada masyarakat. Program pemberdayaan ini berfungsi sebagai bentuk tanggungjawab perusahaan terhadap masyarakat sekitar perkebunan kelapa sawit. Pemberdayaan masyarakat bertujuan agar masyarakat lebih berdaya dan mandiri, sehingga terjadi peningkatan kesejahteraan masyarakat sekitar perusahaan perkebunan kelapa sawit.

\section{REFERENSI}

Afrizal. (2006). Sosiologi Konflik Agraria: Protes-Protes Agraria Dalam Masyarakat Indonesia Kontemporer. Padang: Andalas University Press.

Argenti, P.A., Howell, R.A., dan Beck, K.A. (2005). The strategic communication imperative. MIT Sloan management review, 46(3), 83.

Astuti, P. (2011). Kekerasan Dalam Konflik Agraria: Kegagalan Negara Dalam Menciptakan Keadilan Di Bidang Pertanahan. FORUM, Vol. 39, No. 2, pp. 52-60.

Berger, C. R., Roloff, M. E., dan Ewoldsen, D. R. (Eds.). (2010). The Handbook of Communication Science. Thousand Oak: Sage Publications.

[BPS Aceh] Badan Pusat Statistik Aceh. (2015). Aceh Dalam Angka tahun 2015. Banda Aceh: BPS Aceh.

Botan, C.H. (2006). Grand Strategy, Strategy, and Tactics in Public Relations. Dalam C.H. Botan dan V. Hazleton (Ed.). Public Relations Theory II. New Jersey: Lawrence Erlbaum Associates.

Bungin, Burhan. (2011). Penelitian Kualitatif: Komunikasi, Ekonomi, Kebijakan Pubik, dan Ilmu Sosial Lainnya. Jakarta: Prenada Media Group.

Cangara, Hafied. (2013). Perencanaan dan Strategi Komunikasi. Jakarta: Rajawali Press.

Cifor. (2016). Konflik Perusahaan-Masyarakat di Sektor Perkebunan Industri Indoensia. Bogor: Info Brief No. 144, Juni 2016.

Creswell, John W. (2014). Research Design: Qualitative, Quantitative, and Mixed Methods Approach (Fourth Edition). Thousand Oak: SAGE Publications.

Colchester, M., et al. (2007). Promised land: palm oil and land acquisition in Indonesia: implications for local communities and indigenous peoples. Perkumpulan Sawit Watch.

Colchester, M. et al. (2011). Ekspansi Kelapa Sawit di Asia Tenggara: Sebuah Tinjauan. Dalam Colcherster dan Chao (ed.), Ekspansi Kelapa Sawit di Asia Negara: 
Kecenderungan dan implikasi bagi masyarakat lokal dan masyarakat adat. Bogor: Perkumpulan Sawit Watch bekerjasama dengan Forest Peoples Programme.

Dade, A. dan Hassenzahl, D. M. (2013). Communicating Sustainability: A Content Analysis Of Website Communications In The United States. International Journal of Sustainability in Higher Education, 14(3), 254-263.

[Dirjen Perkebunan] Direktorat Jenderal Perkebunan. (2015). Statistik Perkebunan Indonesia 2013-2015: Kelapa Sawit. Kementerian Pertanian Republik Indonesia.

Ellis, Donald G. (2014). Konflik Antarkelompok. Dalam Berger et al (Ed). Handbook Ilmu Komunikasi. Terj. Derta Sri Widowatie. Bandung: Penerbit Nusa Media.

Fauzi, N. (2008). Gelombang Baru Reforma Agraria Di Awal Abad Ke-21. Universitas Indonesia, Depok.

Fitzherbert, E. B. et al. (2008). How Will Oil Palm Expansion Affect Biodiversity?. Trends in ecology \& evolution, 23(10), 538-545.

Gilboa, Eytan. (2009). Media and Conflict Resolution: A Framework for Analysis, 93 Marq. L. Rev. 87, hal. 87-110.

Gilchrist, Alison. (2009). The Well-Connected Community; A Network Approach to Communicaty Development. Great Britain: The Policy Press.

[GTZ] Deutsche Gesellschaft für Internationale Zusammenarbeit. (2006). Strategic Communication for Sustainable Development. Bonn: GTZ Rioplus.

Hallahan, K., Holtzhausen, D., Van Ruler, B., Verčič, D., dan Sriramesh, K. (2007). Defining strategic communication. International journal of strategic communication, 1(1), 3-35.

Hall, Derek, Philip Hirsch, dan Tania Murray Li. (2011). Power of Exclusion, Land Dilemmas in Southeast Asia, Singapore: National University of Singapore.

Jalil, M. (2014). Strategi Komunikasi Tokoh Masyarakat Dalam Menyelesaikan Konflik Sengketa Tanah Di Desa Pasir Belengkong Kecamatan Pasir Belengkong Kabupaten Paser. E-journal Ilmu Komunikasi, 2(4), 15-29.

Kartikasari, S. N. (2000). Mengelola Konflik: Keterampilan \& Strategi Untuk bertindak. Jakarta: The British Council.

[KPA] Konsorsium Pembaruan Agraria. (2014). Catatan Akhir Tahun 2014 Konsorsium Pembaruan Agraria; Membenahi Masalah Agraria-Prioritas Kerja Jokowi-JK Tahun 2015. Jakarta: Konsorsium Pembaruan Agraria.

[KPA] Konsorsium Pembaruan Agraria. (2015). Catatan Akhir Tahun 2015 Konsorsium Pembaruan Agraria; Reforma Agraria dan Penyelesaian Konflik Agraria Disandera Birokrasi. Jakarta: Konsorsium Pembaruan Agraria.

[KPA] Konsorsium Pembaruan Agraria. (2016). Catatan Akhir Tahun 2016 Konsorsium Pembaruan Agraria; Liberalisasi Agraria Diperhebat, Reforma Agraria Dibelokkan. Jakarta: Konsorsium Pembaruan Agraria.

Kriyantono, Rachmat. (2006). Teknik Praktis Riset Komunikasi. Jakarta: Prenada Media Group.

Kymlicka, W dan Bashir B (Ed.). (2008). The Politics of Reconciliation in Multicultural Societies. Oxford: Oxford University Press.

Littlejohn, Stephen W dan Kathy Domenici. (2001). Engaging Communication in Conflict: Systemic Practice. Thousand Oak: SAGE Publications.

Littlejohn, Stephen W dan Kathy Domenici. (2007). Communication, Conflict, and Management of Different. Illinois: Waveland Press.

Lusiana, Susan. (2007). Konflik Agraria: Buah Ketimpangan Struktur Penguasaan Agraria. Pembaruan Tani, Mimbar Komunikasi Petani, Edisi 40, 6-7. 
Luthfi, Ahmad Nashih. (2013). Review Buku: Ekslusi dan Inklusi Sebagai Dua Sisi Mata Uang. Bhumi, Jurnal Ilmiah Pertanahan PPPM-STPN, Nomor 37(12), 196-199.

Maladi, Y. (2012). Dominasi Negara Sebagai Sumber Konflik Agraria di Indonesia. MASALAH-MASALAH HUKUM, 41(3).

Manheim. (2011). Strategy in information and Influence Campaign: How Policy Advocates, Social Movement, Insurgent Groups, Corporation, Government, and Others Get What They Want. New York: Routledge.

Mutolib, A., et al. (2016). Konflik Agraria dan Pelepasan Tanah Ulayat (Studi Kasus Pada Masyarakat Suku Melayu di Kesatuan Pemangkuan Hutan Dharmasraya, Sumatera Barat). Jurnal Penelitian Sosial dan Ekonomi Kehutanan, 12(3), 213-225.

Nantha, H. S., dan Tisdell, C. (2009). The orangutan-oil palm conflict: economic constraints and opportunities for conservation. Biodiversity and Conservation, 18(2), 487-502.

Palupi, Sri et al. (2014). Industri Perkebunan dan Hak Asasi Manusia: Potret Pelaksanaan Tanggung Jawab Pemerintah dan Korporasi terhadap Hak Asasi Manusia di Kalimantan Tengah. Jakarta: The Institute for Ecosoc Rights.

Pfetsch, B. (1998). Government News Management. Dalam D.A.Graber, D. McQuail, dan P. Norris (Ed.). The Politics of News: The News of Politics. Washington: CQ Press.

Plowman, K.D. (2011). Strategic Communication Planning: A Multiple Case Study from Iraq and Kuwait. Proceedings of the 14th International Public Relations Research Conference, hal. 689-706.

Plowman, K.D. dan Wakefield, R.I. (2013). Strategic Communication and Conflict Resolution. Dalam Krishnamurthy Sriramesh, Ansgar Zerfass, dan Jeong-Nam Kim (Ed.). Public Relations and Communication Management: Current Trends and Emerging Topics. New York: Taylor \& Francis.

Poloma, Margaret. (2013). Sosiologi Kontemporer. Terj. Tim Penerjemah YASOGAMA. Jakarta: RajaGrafindo Persada.

Potter, L. dan Lee, J. (1998). Tree planting in Indonesia: Trends, impacts and directions. CIFOR Occasional Paper no.18, hal. 85.

Putnam, L.L. (2006). Definitions and approaches to conflict and communication. The Sage handbook of conflict communication: Integrating theory, research, and practice, 132.

Putnam, L.L. (2009). Exploring the Role of Communication in Transforming Conflict Situation; A Social Construction View. Dalam G.J. Galanes dan W. Leeds-Hurwitz (Ed.). Social Constructing Communication. New Jersey: Hampton Press.

Putnam, L.L. (2010). Negotiation and discourse analysis. Negotiation Journal, 26(2), 145154.

Rahman S.H. et al. (2008). Soaring Food Prices: Response To The Crisis. Manila: Asian Development Bank.

Ribot, J.C., dan Peluso, N.L. (2003. A theory of access. Rural sociology, 68(2), 153-181.

Richardson, C.L. (2010). Deforestation due to palm oil plantations in Indonesia. Towards the sustainable production of Palm Oil, Australia.

Rist, L., Feintrenie, L., dan Levang, P. (2010). The livelihood impacts of oil palm: smallholders in Indonesia. Biodiversity and conservation, 19(4), 1009-1024.

Sen, Amartya. (2016). Kekerasan dan Identitas. Penj. Arif Susanto. Serpong: Marjin Kiri.

Sillars, Alan L. (2014). Konflik Interpersonal. Dalam Berger et al (2014). Handbook Ilmu Komunikasi. Terj. Derta Sri Widowatie. Bandung: Penerbit Nusa Media.

Sindung, Karyanto. (2012). Spektrum Teori Sosial: Dari Klasik Hingga Post-modern. Yogyakarta: Ar-Ruzz Media.

Soetomo. (2015). Masalah Sosial dan Upaya Pencegahannya. Yogyakarta: Pustaka Pelajar. 
Syafi'i, Imam. (2016). Konflik Agraria di Indonesia: Catatan Reflektif Konflik Perkebunan Kelapa Sawit di Kotawaringin Timur. Jurnal Masyarakat dan Budaya, 18(3), hal, 415-432.

Viso, Ana Fernandez. (2014). Peace Communication for Social Change: Dealing With Violent Conflict. Dalam Karin Gwinn Wilkins et al (Ed.). 2014. The Handbook of Development Communiaction and Social Change. Oxford: Wiley Blackwell.

Wakker, E., Watch, S., dan Rozario, J. D. (2004). Greasy Palms: The Social And Ecological Impacts Of Large-Scale Oil Palm Plantation Development In Southeast Asia. Greasy palms: the social and ecological impacts of large-scale oil palm plantation development in Southeast Asia.

Waisbord, Silvio. (2014). The Strategic Politic of Participatory Communication. Dalam Karin Gwinn Wilkin, Thomas Tufte, dan Rafael Obregon (ed.). The Handbook of Development Communication and Social Change. Oxford: Wiley Blackwell.

Wicke, B., Sikkema, R., Dornburg, V., dan Faaij, A. (2011). Exploring Land Use Changes and the Role of Palm Oil Production in Indonesia and Malaysia. Land use policy, 28(1), 193-206.

Widiyanto, Sri Maryanti, dan S. Rakhma Mary. (2012). Outlook Konflik Sumebr Day Alam dan Agraria 2012. Jakarta: HuMa.

Wood. Julia T. (2009). Communication in Our Live. Boston: Cengage Learning.

Yin, R.K. (2012). Applications of Case Study Research: Third Edition. Thousand Oak: SAGE Publications. 